\title{
Pengaruh Penambahan Ragi Tape dan Waktu Fermentasi Hasil Samping Cairan Pulpa terhadap Karakteristik Mutu Cuka Kakao (Theobroma cacao L.)
}

\author{
Ida Bagus Gede Awidyanata, Gusti Putu Ganda Putra*, Luh Putu Wrasiati \\ PS Teknologi Industri Pertanian, Fakultas Teknologi Pertanian, Universitas Udayana, Kampus Bukit \\ Jimbaran, Badung, Kode pos : 80361; Telp/Fax : (0361) 701801.
}

Diterima 29 Oktober 2019 / Disetujui 13 Januari 2020

\begin{abstract}
The aim of this study was to determine the effect of adding ragi tape and the time of natural fermentation of the pulp byproducts of the fermented cocoa beans on the characteristics of the quality of cocoa vinegar and determining the addition of tape yeast and the natural fermentation time of the best pulp fluid for cocoa vinegar production. The experiments in this study used a randomized block design with two factors. The first factor is the addition of yeast tape consisting of 5 levels, namely without the addition of yeast tape (control), the addition of yeast tape $0.05 \%(w / v), 0.10 \%(w / v), 0.15 \%(w / v)$, $0.20 \%(w / v)$, the second factor is the fermentation time consisting of 6 levels, namely 5, 10, 15, 20, 25, 30 days. Treatment The addition of tape yeast has a very significant effect on acetic acid, pH, total dissolved solids, total sugar, has no significant effect on alcohol content in the fermented vinegar from the pulp fluid which is the by-product of cocoa bean fermentation. The length of fermentation treatment has a very significant effect on acetic acid, pH, total dissolved solids, total sugar, alcohol. The interaction between the two treatments had no significant effect on acetic acid, $\mathrm{pH}$, total dissolved solids, alcohol content, and significant effect on total sugar in fermented cocoa vinegar products. The best treatment was obtained from the addition of $0.15 \%(w / v)$ yeast tape and 30 days fermentation time which produced cacao vinegar with acetic acid content of $2.40 \%$, pH 3.37, total dissolved solids 4.25 ${ }^{\circ}$ brix, total sugar $0.03 \%$, and $0.00 \%$ alcohol.
\end{abstract}

Keywords : vinegar fermentasion, ragi tape, time of fermentation

\section{ABSTRAK}

Tujuan penelitian ini yaitu untuk mengetahui pengaruh penambahan ragi tape dan waktu fermentasi alami cairan pulpa hasil samping fermentasi biji kakao terhadap karakteristik mutu cuka kakao dan menentukan penambahan ragi tape dan waktu fermentasi alami cairan pulpa yang terbaik untuk pembuatan cuka kakao. Percobaan dalam penelitian ini menggunakan Rancangan Acak Kelompok dengan dua faktor. Faktor pertama adalah penambahan ragi tape yang terdiri dari 5 level, yaitu tanpa penambahan ragi tape (kontrol), penambahan ragi tape $0,05 \%(\mathrm{~b} / \mathrm{v}), 0,10 \%(\mathrm{~b} / \mathrm{v}), 0,15 \%(\mathrm{~b} / \mathrm{v}), 0,20 \%$ (b/v), faktor kedua adalah waktu fermentasi yang terdiri dari 6 level, yaitu 5, 10, 15, 20, 25, 30 hari. Perlakuan Penambahan ragi tape berpengaruh sangat nyata terhadap asam asetat, $\mathrm{pH}$, total padatan terlarut, total gula, berpengaruh tidak nyata terhadap kadar alkohol pada cuka fermentasi dari cairan pulpa hasil samping fermentasi biji kakao. Perlakuan lama fermentasi berpengaruh sangat nyata terhadap asam asetat, $\mathrm{pH}$, total padatan terlarut, total gula, alkohol. Interaksi antara kedua perlakuan berpengaruh tidak nyata terhadap asam asetat, $\mathrm{pH}$, total padatan terlarut, kadar alkohol, dan berpengaruh

\footnotetext{
*Korespondensi Penulis:

Email : gandaputra@unud.ac.id
} 
sangat nyata terhadap total gula pada produk cuka kakao fermentasi. Perlakuan terbaik diperoleh dari penambahan ragi tape $0,15 \%(\mathrm{~b} / \mathrm{v})$ dan waktu fermentasi 30 hari yang menghasilkan cuka kakao dengan kadar asam asetat 2,40\%, $\mathrm{pH} 3,37$, total padatan terlarut $4,25^{\circ}$ brix, total gula $0,03 \%$, dan alkohol $0,00 \%$.

Kata kunci : fermentasi cuka, ragi tape, waktu fermentasi

\section{PENDAHULUAN}

Indonesia merupakan negara penghasil kakao terbesar ketiga di dunia dengan jumlah produksi pertahun 270.000 ton setelah Ivory Coast (2.020.000 ton) dan Ghana (969.000 ton) (ICCO, 2019). Buah kakao terdiri dari 75,52 persen kulit buah, 2,20 persen plasenta dan 22,28 persen biji (Djatmiko et al., 1989). Tanaman kakao diperkenalkan pertama kali di Indonesia pada tahun 1560 , tepatnya di Sulawesi, Minahasa. Luas perkebunan areal tanaman kakao di Indonesia hingga saat ini diperkirakan telah mencapai 1.722.315 ha, dengan jumlah produksi kakao sebanyak 760.429 ton (Ditjen Perkebunan, 2016).

Dalam proses pengolahan biji kakao kering, proses fermentasi dianggap proses yang paling dominan mempengaruhi mutu biji kakao kering (Alamsyah, 1991). Fermentasi biji kakao bertujuan_untuk menghancurkan pulpa dan mengusahakan kondisi untuk terjadinya reaksi biokimia dalam keping biji, yang berperan bagi pembentukan cita rasa dan warna coklat. Pulpa yang telah hancur akan mudah lepas dari biji. Fermentasi biji kakao bertujuan untuk menghancurkan pulpa dan mengusahakan kondisi untuk terjadinya reaksi biokimia dalam keping biji, yang berperan bagi pembentukan cita rasa dan warna coklat. Pulpa yang telah hancur akan mudah lepas dari biji, membentuk cairan pulpa (watery sweatings) yang menetes keluar tumpukan biji. Selama fermentasi dapat dihasilkan cairan pulpa $15-20 \%$ dari berat biji kakao yang difermentasi (GandaPutra et al., 2008). Pulpa merupakan jaringan halus berlendir yang melekat ketat pada biji kakao. Cairan pulpa hasil fermentasi biji kakao seringkali dianggap limbah yang jarang dimanfaatkan dan dibuang langsung ke lingkungan dan menyebabkan pencemaran. Menurut Case (2004), cairan pulpa hasil fermentasi kakao mengandung $1,6 \%$ asam asetat, asam sitrat $0,5 \%$, dengan pH 6,5 dan etil alkohol 0,5\%. Di dalam pulpa biji kakao juga mengandung gula dengan kadar yang relatif tinggi sekitar 10-13\% (Lopez, 1986). Adanya kandungankandungan tersebut pada cairan pulpa kakao, serta untuk meningkatkan nilai tambah, cairan pulpa kakao dapat dimanfaatkan untuk dijadikan suatu produk, salah satunya adalah cuka fermentasi.

Prinsip pembuatan cuka buah yaitu fermentasi asam asetat. Proses ini melibatkan aktivitas bakteri Acetobacter aceti yang mengubah alkohol dengan kadar tertentu menjadi sejumlah asam asetat dalam kondisi aerob (Anonim, 2009). Menurut Daulay dan Rahman (1992), kriteria mutu cuka yang utama adalah kandungan asam asetatnya. Mikroba yang umum digunakan dalam pembentukan asam asetat adalah bakteri Acetobacter aceti. Pada pembuatan asam cuka dari pisang kepok dengan konsentrasi inokulum Acetobacter aceti 15\% diperoleh kadar asam asetat tertinggi yaitu $4,32 \%$ dibandingkan dengan penambahan inokulum sebanyak 5\% atau $10 \%$ (Nurismanto et al., 2014).

Ragi tape adalah salah satu jenis dari biakan campuran yang memiliki peluang untuk memproses cairan pulpa dari biji kakao secara fermentasi, kalau dilihat dari komposisi mikroba yang terdapat pada ragi tersebut. Ragi tape mengandung bakteri Acetobacter aceti dan mengandung berbagai macam mikroba antara lain Candida sp., Endomycopsis sp., Hansenula sp., Amylomyces sp., Aspergillus sp., fusarium sp., Mucor sp. dan rhizopus sp. (Steinkraus, 1983), yang sangat berperan dalam proses 
fermentasi . dan dapat membantu dalam pembentukan asam asetat. Mikroorganisme yang terdapat didalam ragi tape juga dapat mengubah glukosa menjadi alkohol dan gas $\mathrm{CO}_{2}$. Dari golongan ragi dikenal beberapa jenis, antara lain ragi tape. Di dalam Ragi tape juga terdapat jenis khamir Saccharomycopsis cerevisiae, yang mempunyai pertumbuhan sempurna pada suhu sekitar $30^{\circ} \mathrm{C}$ dan $\mathrm{pH}$ 4,8.. Penambahan ragi tape pada fermentasi biji kakao dengan kisaran $1,0 \%$ telah dicobakan oleh (Agung et al., 1998), yang dapat mempersingkat waktu fermentasi menjadi 4 hari dari 6 hari pada fermentasi alami, dengan hasil biji kakao kering mutu I. Kondisi demikian terjadi karena penguraian gula pulpa berlangsung lebih cepat dan sempurna.Lama fermentasi termasuk faktor yang menentukan tinggi rendahnya asam asetat yang terbentuk. Menurut hasil penelitian (Adrista et al., 2016) mengenai pengaruh penambahan etanol dan lama fermentasi cairan pulpa kakao terhadap karakteristik cuka fermentasi, penambahan etanol sebesar 5\% dengan lama fermentasi 10 hari hanya mampu menghasilkan asam asetat sebanyak $2,82 \%$.

Dalam penelitian (Aridona et al., 2015) mengenai pengaruh lama fermentasi alami secara aerob cairan pulpa kakao terhadap karakteristik cuka fermentasi, dilakukan fermentasi aerob dengan menggunakan aerator berupa pompa air aquarium selama 10 hari, dan menghasilkan kadar asam asetat tertinggi sebanyak 2,30 \% (v/v) dari lama fermentasi 6 hari. Sedangkan, menurut hasil penelitian (Putri et al., 2016), mengenai pembuatan cuka fermentasi dari cairan pulpa kakao dengan pengaruh penambahan inokulum Saccharomycess cerevisiae dan lama fermentasi, asam asetat tertinggi diperoleh dari fermentasi selama 25 hari, yaitu sebesar 2,86\% (v/v). Dari hasil penelitian tersebut kadar asam asetat yang terbentuk masih tergolong rendah dan tidak memenuhi standar kadar asam asetat yang disyaratkan oleh SNI 01-4371-1996 yaitu minimal sebesar 4\%. Sebaliknya, konsentrasi alkohol yang tinggi atau lebih dari $12 \%$, akan memperlemah bahkan menjadi racun bagi aktivitas Acetobacter aceti (Hardoyo et al., 2007). Didasari oleh penelitian sebelumnya, maka dilakukan penelitian dengan perlakuan pengaruh penambahan ragi tape dan lama fermentasi pada proses fermentasi cuka dari cairan pulpa hasil samping fermentasi biji kakao. Dengan ini dapat menetapkan penambahan ragi tape dan waktu fermentasi yang optimum untuk memperoleh cuka kakao yang terbaik.

\section{METODE PENELITIAN}

\section{Tempat dan Waktu}

Penelitian ini dilakukan di Laboratorium Rekayasa Proses dan Pengendalian Mutu dan Laboratorium Analisis Pangan Fakultas Teknologi Pertanian Universitas Udayana. Penelitian ini dilakukan pada Juli sampai September 2018.

\section{Alat dan Bahan}

Peralatan yang digunakan pada penelitian yaitu wadah fermentasi (gallon dan toples plastik), pengaduk magnetik, water bath, $\mathrm{pH}$ meter, hand refraktometer, oven inkubator, alat distilasi, aerator aquarium, botol sampel, gelas ukur (Herma, Iwaki), ayakan 60 mesh (Retsch), aluminium foil, pipet tetes, $\mathrm{pH}$ meter. Peralatan yang digunakan untuk analisis terdiri dari timbangan analitik (SHIMADZU-ATY224), Erlenmeyer (Duran), gelas beaker (Pyrex, Iwaki), penjepit, desikator (Duran), tabung reaksi (Iwaki), kertas saring kasar, pipet volume (Iwaki), spektrofotometer (Genesys 10S UV-VIS), vortex (Barnstead Thermolyne Maxi Mix II), dan mikro buret (EMhirschmann).

Bahan utama yang digunakan pada penilitian ini yaitu cairan pulpa hasil samping fermentasi biji kakao selama 1-2 hari, yang 
diperoleh dari petani di Desa Angkah, Kecamatan Selemadeg Barat, Kabupaten Tabanan, Bali. Sedangkan bahan - bahan lain yang digunakan untuk proses yaitu ragi tape, alkohol, standar asam galat, methanol, folin ciocalteu's, $\mathrm{Na}_{2} \mathrm{CO}_{3}$, indakator pp $1 \%$, glukosa, nelson, $\mathrm{HCl}$, arsenomolibdat, dan bahan kimia untuk analisis hasil.

\section{Rancangan Percobaa}

Rancangan percobaan dalam penelitian ini menggunakan Rancangan Acak Kelompok (RAK) dengan dua faktor. Faktor I adalah penambahan ragi tape (R) yang terdiri atas 5 taraf, yaitu R0 = Tanpa penambahan ragi tape (kontrol), $\mathrm{R} 1=$ Penambahan ragi tape $0,05 \%(\mathrm{~b} / \mathrm{v}), \mathrm{R} 2=$ Penambahan ragi tape $0,10 \%(\mathrm{~b} / \mathrm{v}), \mathrm{R} 3=$ Penambahan ragi tape $0,15 \%(\mathrm{~b} / \mathrm{v}), \mathrm{R} 4=$ Penambahan ragi tape $0,20 \%(\mathrm{~b} / \mathrm{v})$, Faktor II yaitu waktu fermentasi $(\mathrm{H})$ yang terdiri atas 6 taraf, yaitu : H5 = Hari ke-5, H10 = Hari ke10, H15 = Hari ke-15, H20 = Hari ke-20, H25 = Hari ke-25, H30 = Hari ke-30. Sehingga diperoleh masing-masing kombinasi perlakuan (30 kombinasi) dibuat dalam 2 kelompok sehingga diperoleh 60 unit percobaan. Data yang diperoleh akan dianalisis dengan analisis sidik ragam untuk mengetahui pengaruh kedua faktor dan interaksinya. Apabila terdapat pengaruh perlakuan terhadap parameter yang diamati, maka akan dilanjutkan dengan uji BNT 5\% bila perlakuan berpengaruh signifikan $(\mathrm{p}<$ 0,05). Perlakuan terbaik ditentukan dengan uji indeks efektifitas (De Garmo et al, 1984).

\section{Pelaksanaan Penelitian}

Cairan pulpa 1 sampai 2 hari disiapkan sebanyak 50 liter untuk 2 kelompok, kelompok 1 sebanyak 25 liter dan kelompok 2 sebanyak 25 liter. Setiap kelompok dibagi ke dalam 5 gallon dan ditambahkan ragi tape yang sudah diayak dengan ayakan 60 mesh sesuai perlakuan yaitu tanpa penambahan ragi tape (kontrol), penambahan ragi tape
$0,05 \%(\mathrm{~b} / \mathrm{v})$, penambahan ragi tape $0,10 \%$ $(\mathrm{b} / \mathrm{v})$, penambahan ragi tape $0,15 \%(\mathrm{~b} / \mathrm{v})$, penambahan ragi tape $0,20 \% \quad(\mathrm{~b} / \mathrm{v})$. Fermentasi dilakukan selama 30 hari, fermentasi anaerob selama 10 hari dan fermentasi aerob selama 20 hari. Analisis pada masing-masing sampel dilakukan setiap 5 hari.

\section{Variabel yang Diamati}

Variabel yang diamati pada cuka hasil samping cairan pulpa kakao adalah : kadar asam asetat (SNI 01-3711-1995), kadar alkohol (SNI 01-4371-1966), pH (Apriyanto et al., 1988), total padatan terlarut (Harijono et al., 2001; Wartini et al., 2014), dan total gula metode nelson somogyi (Sudarmadji at al., 1984).

\section{HASIL DAN PEMBAHASAN}

\section{Kadar Asam Asetat}

Hasil analisis keragaman menunjukan bahwa perlakuan lama fermentasi dan penambahan ragi tape berpengaruh sangat nyata $(\mathrm{P}<0,01)$, tetapi interaksi antar kedua perlakuan tidak berpengaruh nyata $(\mathrm{P}>0,05)$ terhadap nilai rata-rata kadar asam asetat pada cuka fermentasi cairan pulpa biji kakao. Nilai rata-rata kadar asam asetat dapat dilihat pada Tabel 1.

Berdasarkan Tabel 1 di atas, nilai rata-rata asam asetat cuka fermentasi dari cairan pulpa hasil samping fermentasi biji kakao pada perlakuan lama fermentasi terjadi peningkatan kadar asam asetat sampai hari ke-30, semakin lama fermentasi maka semakin tinggi kadar asam asetat pada cairan pulpa biji kakao. Hal tersebut diduga terjadi karena penambahan ragi tape selama fermentasi menghasilkan cairan pulpa dengan kadar total asam yang signifikan lebih tinggi dibandingkan dengan penambahan yang lain dan juga kontrol. Semakin tinggi penambahan ragi maka mikroba yang ada di cairan pulpa semakin banyak, sehingga semakin banyak asam asetat yang dihasilkan. Hal tersebut terjadi karena penambahan ragi tape memberikan kondisi yang lebih baik pada penguraian gula 
pulpa menjadi asam-asam organik, terutama asam

asetat.

Tabel 1. Nilai rata-rata kadar asam asetat (\%) cuka kakao.

\begin{tabular}{ccccccc}
\hline \multirow{2}{*}{$\begin{array}{c}\text { Lama fermentasi } \\
\text { (Hari) }\end{array}$} & \multicolumn{7}{c}{ Konsentrasi Penambahan Ragi Tape (\%) } & Rata-rata \\
\cline { 2 - 6 } & 0 & 0,05 & 0,10 & 0,15 & 0,20 & \\
\hline 5 & 1,35 & 1,36 & 1,64 & 1,81 & 1,81 & $1,59 \pm 0,23^{\mathrm{e}}$ \\
10 & 1,38 & 1,39 & 1,61 & 1,91 & 1,89 & $1,64 \pm 0,26^{\text {de }}$ \\
15 & 1,44 & 1,47 & 1,67 & 1,92 & 1,90 & $1,68 \pm 0,23^{\mathrm{d}}$ \\
20 & 1,50 & 1,54 & 1,76 & 2,03 & 2,02 & $1,77 \pm 0,25^{\mathrm{c}}$ \\
25 & 1,60 & 1,67 & 1,88 & 2,09 & 2,08 & $1,86 \pm 0,23^{\mathrm{b}}$ \\
30 & 1,68 & 1,80 & 1,95 & 2,40 & 2,30 & $2,03 \pm 0,31^{\mathrm{a}}$ \\
\hline Rata-rata & $1,49 \pm 0,13^{\mathrm{c}}$ & $1,54 \pm 0,17^{\mathrm{c}}$ & $1,75 \pm 0,14^{\mathrm{b}}$ & $2,03 \pm 0,21^{\mathrm{a}}$ & $2,00 \pm 0,18^{\mathrm{a}}$ & \\
\hline
\end{tabular}

Keterangan: Huruf yang berbeda di belakang nilai rata-rata pada baris atau kolom yang sama menunjukkan adanya perbedaan yang nyata $(\mathrm{P}<0,05)$. Data merupakan rata-rata dari dua kelompok percobaan.

Hal ini didukung dengan hasil penelitian Hardoyo et al. (2007) yang menunjukkan bahwa fermentasi asam asetat pada media Hoyer dengan menggunakan bakteri Acetobacter aceti B166 pada kondisi fermentasi suhu $30^{\circ} \mathrm{C}$ dengan lama fermentasi 3-12 hari, menunjukkan bahwa lama fermentasi menghasilkan kadar asam asetat tertinggi pada hari ke-11. Menurut Syarief (2009), mikroba Acetobacter aceti banyak tumbuh dan membelah diri sehingga jumlahnya meningkat dengan cepat. Semakin lama fermentasi maka Acetobacter aceti akan lebih aktif untuk mengubah alkohol menjadi asam asetat sehingga keasaman akan semakin tinggi.

\section{pH}

Hasil analisis keragaman menunjukan bahwa perlakuan lama fermentasi dan penambahan ragi tape berpengaruh sangat nyata $(\mathrm{P}<0,01)$, tetapi interaksi antar kedua perlakuan tidak berpengaruh nyata $(\mathrm{P}>0,05)$ terhadap nilai rata-rata $\mathrm{pH}$ pada cuka fermentasi cairan pulpa biji kakao. Nilai ratarata $\mathrm{pH}$ dapat dilihat pada Tabel 2.

Tabel 2. Nilai rata-rata $\mathrm{pH}$ cuka kakao.

\begin{tabular}{|c|c|c|c|c|c|c|}
\hline \multirow{2}{*}{$\begin{array}{l}\text { Lama fermentasi } \\
\text { (Hari) }\end{array}$} & \multicolumn{5}{|c|}{ Konsentrasi Penambahan Ragi Tape (\%) } & \multirow{2}{*}{ Rata-rata } \\
\hline & 0 & 0.05 & 0.10 & 0.15 & 0.20 & \\
\hline 5 & 3,94 & 3,90 & 3,83 & 3,75 & 3,76 & $3,84 \pm 0,08^{a}$ \\
\hline 10 & 3,86 & 3,83 & 3,79 & 3,71 & 3,71 & $3,78 \pm 0,07^{b}$ \\
\hline 15 & 3,79 & 3,75 & 3,72 & 3,64 & 3,65 & $3,71 \pm 0,06^{\mathrm{c}}$ \\
\hline 20 & 3,73 & 3,70 & 3,66 & 3,59 & 3,59 & $3,65 \pm 0,06^{\mathrm{d}}$ \\
\hline 25 & 3,64 & 3,59 & 3,52 & 3,46 & 3,47 & $3,54 \pm 0,08^{\mathrm{e}}$ \\
\hline 30 & 3,58 & 3,51 & 3,42 & 3,37 & 3,37 & $3,45 \pm 0,09^{\mathrm{f}}$ \\
\hline Rata-rata & $3,76 \pm 0,13^{\mathrm{a}}$ & $3,71 \pm 0,15^{b}$ & $3,66 \pm 0,16^{c}$ & $3,59 \pm 0,15^{\mathrm{d}}$ & $3,59 \pm 0,15^{\mathrm{d}}$ & \\
\hline
\end{tabular}

Keterangan: Huruf yang berbeda di belakang nilai rata-rata pada baris atau kolom yang sama menunjukkan adanya perbedaan yang nyata $(\mathrm{P}<0,05)$. Data merupakan rata-rata dari dua kelompok percobaan. 
Tabel 2 menunjukkan bahwa semakin lama fermentasi, maka $\mathrm{pH}$ cuka kakao semakin rendah. Hal ini berkaitan dengan kadar asam asetat, jika semakin tinggi, maka pH pada cuka kakao semakin rendah. Menurut Said (1984) nilai pH substrat yang rendah menunjukkan bahwa substrat tersebut bersifat asam. Hasil penelitian Aridona (2015) juga menyatakan bahwa semakin lama fermentasi maka semakin banyak alkohol yang diubah menjadi asam oleh mikroba sehingga kondisi fermentasi menjadi asam yang menyebabkan $\mathrm{pH}$ cairan pulpa menurun.

Pada Tabel 2 diatas menunjukkan bahwa pH pulpa biji kakao mengalami penurunan pada setiap penambahan ragi cairan pulpa kakao dari hari ke-5 sampai hari ke-30. Hal ini disebabkan terbentuknya asam
- asam organik hasil pemecahan gula yang ada oleh mikroba. Semakin banyak penambahan ragi semakin banyak juga mikroba yang melakukan fermentasi pada pulpa biji kakao. Menurut Anon (2014) semakin tinggi presentase ragi yang ditambahkan maka semakin banyak karbohidrat yang dirombak menjadi glukosa, alkohol, asam laktat dan senyawa lainnya.

\section{Total padatan terlarut (TPT)}

Hasil analisis keragaman menunjukan bahwa perlakuan lama fermentasi dan penambahan ragi tape berpengaruh sangat nyata $(\mathrm{P}<0,01)$, tetapi interaksi antar kedua perlakuan tidak berpengaruh nyata $(\mathrm{P}>0,05)$ terhadap nilai rata-rata TPT pada cuka fermentasi cairan pulpa biji kakao. Nilai ratarata TPT dapat dilihat pada Tabel 3.

Tabel 3. Nilai rata-rata TPT (oBrix) cuka kakao.

\begin{tabular}{ccccccc}
\hline $\begin{array}{c}\text { Lama fermentasi } \\
\text { (Hari) }\end{array}$ & \multicolumn{5}{c}{ Konsentrasi Penambahan Ragi Tape (\%) } & \multirow{2}{*}{ Rata-rata } \\
\cline { 2 - 6 } & 0 & 0.05 & 0.10 & 0.15 & 0.20 & \\
\hline 5 & 6,58 & 6,58 & 6,30 & 6,08 & 6,13 & $6,33 \pm 0,24^{\mathrm{a}}$ \\
10 & 6,18 & 6,18 & 5,95 & 5,68 & 5,73 & $5,94 \pm 0,24^{\mathrm{b}}$ \\
15 & 5,60 & 5,63 & 5,45 & 5,20 & 5,23 & $5,42 \pm 0,20^{\mathrm{c}}$ \\
20 & 5,60 & 5,45 & 5,48 & 5,13 & 5,18 & $5.37 \pm 0,20^{\mathrm{c}}$ \\
25 & 5,35 & 5,25 & 5,15 & 4,45 & 4,33 & $4.91 \pm 0,48^{\mathrm{d}}$ \\
30 & 5,50 & 4,53 & 4,60 & 4,25 & 4,30 & $4.64 \pm 0,51^{\mathrm{e}}$ \\
\hline Rata-rata & $5,80 \pm 0,47^{\mathrm{a}}$ & $5,60 \pm 0,72^{\mathrm{b}}$ & $5,49 \pm 0,60^{\mathrm{b}}$ & $5.13 \pm 0,70^{\text {cd }}$ & $5,15 \pm 0,73^{\mathrm{c}}$ & \\
\hline
\end{tabular}

Keterangan: Huruf yang berbeda di belakang nilai rata-rata pada baris atau kolom yang sama menunjukkan adanya perbedaan yang nyata $(\mathrm{P}<0,05)$. Data merupakan rata-rata dari dua kelompok percobaan.

Dari data Tabel 3 menunjukan nilai rata-rata TPT pada cuka fermentasi cenderung menurun selama proses fermentasi. Semakin menurunnya TPT seiring dengan lamanya proses fermentasi berlangsung, diduga disebabkan karena gula yang merupakan komponen padatan yang dominan dalam medium dimanfaatkan oleh bakteri asam asetat sebagai sumber karbon sehingga total padatan terlarut menjadi rendah (Sintasari et al., 2014), selain itu penurunan nilai rata-rata TPT diduga disebabkan karena adanya proses fermentasi oleh mikroba. Karbohidrat (dalam hal ini sukrosa) menjadi substrat utama yang dipecah oleh mikroba dalam proses fermentasi menjadi unit-unit gula yang lebih sederhana (Farikha et al., 2014). Adanya penurunan TPT juga diperoleh sebelumnya pada penelitian Haumasse (2009) mengenai pembuatan cuka dengan penambahan ragi roti, yang menunjukan bahwa semakin lama 
fermentasi maka TPT substrat semakin rendah.

\section{Kadar Total Gula}

Hasil analisis keragaman menunjukan bahwa perlakuan dan interaksi antar kedua perlakuan berpengaruh sangat nyata $(\mathrm{P}<0,01)$ terhadap rata-rata kadar total gula pada cuka fermentasi cairan pulpa biji kakao. Nilai ratarata kadar total gula dapat dilihat pada Tabel 4.

Tabel 4. Nilai rata-rata kadar total gula (\%) cuka kakao.

\begin{tabular}{cccccc}
\hline \multirow{2}{*}{$\begin{array}{c}\text { Lama fermentasi } \\
\text { (Hari) }\end{array}$} & \multicolumn{5}{c}{ Konsentrasi Penambahan Ragi Tape $(\%)$} \\
\cline { 2 - 6 } & 0 & 0.05 & 0.10 & 0.15 & 0.20 \\
\hline 5 & $0.13 \pm 0.01^{\mathrm{ab}}$ & $0.11 \pm 0.01^{\mathrm{bcd}}$ & $0.12 \pm 0.02^{\mathrm{bc}}$ & $0.12 \pm 0.01^{\mathrm{bc}}$ & $0.15 \pm 0.01^{\mathrm{a}}$ \\
10 & $0.11 \pm 0.01 \mathrm{~b}^{\mathrm{cd}}$ & $0.10 \pm 0.01^{\mathrm{cde}}$ & $0.09 \pm 0,00^{\mathrm{def}}$ & $0.09 \pm 0.01^{\mathrm{efg}}$ & $0.08 \pm 0.01^{\mathrm{fghi}}$ \\
15 & $0.09 \pm 0,00^{\mathrm{def}}$ & $0.08 \pm 0,00^{\mathrm{efgh}}$ & $0.08 \pm 0.01^{\mathrm{fghi}}$ & $0.07 \pm 0,00^{\mathrm{fghij}}$ & $0.07 \pm 0.01^{\mathrm{ghijk}}$ \\
20 & $0.07 \pm 0.01^{\text {ghijk }}$ & $0.06 \pm 0.01^{\mathrm{ijkl}}$ & $0.06 \pm 0.01^{\mathrm{ijkl}}$ & $0.04 \pm 0,00^{\mathrm{lmn}}$ & $0.04 \pm 0,00^{\mathrm{lmn}}$ \\
25 & $0.06 \pm 0,00^{\mathrm{hijk}}$ & $0.05 \pm 0,00^{\mathrm{jklm}}$ & $0.05 \pm 0^{\mathrm{jklm}}$ & $0.04 \pm 0,00^{\mathrm{Imn}}$ & $0.04 \pm 0,00^{\mathrm{lmn}}$ \\
30 & $0.06 \pm 0.01^{\mathrm{ijkl}}$ & $0.05 \pm 0.01^{\mathrm{klm}}$ & $0.05 \pm 0.01^{\mathrm{klm}}$ & $0.03 \pm 0,00^{\mathrm{mn}}$ & $0.02 \pm 0,00^{\mathrm{n}}$ \\
\hline
\end{tabular}

Dari data Tabel 4 diatas menunjukan terjadi penurunan total gula pada perlakuan penambahan ragi tape dari hari ke-5 sampai hari ke-30. Hal ini disebabkan karena aktivitas enzim invertase yang berperan dalam penguraian sukrosa menjadi gula reduksi dapat berjalan baik. Menurut Tomlins (et al.,1993) pada fermentasi alami gula yang terdapat dalam biji berupa sukrosa, selama fermentasi diubah menjadi glukosa dan fruktosa oleh enzim invertase.Menurut Lehninger (1982), produksi asam cuka melalui 2 tahap, pada tahapan pertama, sukrosa mengalami reduksi menjadi glukosa, kemudian glukosa menjadi etanol melalui jalur fermentasi. Pada tahap berikutnya terjadi oksidasi dari etanol menjadi asam cuka, perubahan tersebut juga melibatkan bakteri Acetobakter aceti.

Selama proses feermentasi, mikroba akan memecah gula untuk melangsungkan hidupnya dan menghasilkan senyawa metabolit berupa asam-asam organik (Januaresti, 2016). Pada fermentasi asam asetat, sumber karbon (biasanya glukosa) dioksidasi menjadi $\mathrm{CO}_{2}$ dan $\mathrm{H}_{2} \mathrm{O}$. Hal demikian menyebabkan kadar gula makin rendah dengan makin lama waktu fermentasi (Daulay dan Rahman, 1992)

\section{Kadar Alkohol}

Hasil analisis keragaman menunjukan bahwa perlakuan lama fermentasi berpengaruh sangat nyata $(\mathrm{P}<0,01)$ tetapi perlakuan penambahan ragi tape dan interaksi antar kedua perlakuan tidak berpengaruh nyata $(\mathrm{P}>0,05)$ terhadap rata-rata kadar total gula pada cuka fermentasi cairan pulpa biji kakao. Nilai rata-rata kadar total gula dapat dilihat pada Tabel 5.

Berdasarkan hasil penentapan kadar alkohol cuka fermentasi, diperoleh hasil bahwa pada tahapan awal fermentasi di hari ke-5 kadar alkohol yang terkandung pada produk sebesar $5 \%$. Setelah proses fermentasi berlangsung, kadar alkohol pada produk sudah tidak terdeteksi pada fermentasi hari ke-10. Hal tersebut dapat dijelaskan bahwa pada saat fermentasi 5 hari mikroba memiliki aktivitas paling besar atau bearada pada logarithmic phase. Hal ini sesuai pendapat Fauzi, (2012), mikroba akan mengalami deklinasi phase dan stationary phase, yaitu jumlah mikroba yang tumbuh semakin 
melambat kemudian diikuti dengan fenomena jumlah mikroba yang mati dan hidup hampir sama sehingga tidak ada penambahan jumlah mikroba yang akan mengubah substrat menjadi etanol oleh karena itu etanol yang terbentuk cenderung konstan. Setelah mikroba mengalami stationary phase maka akan berlanjut menjadi death phase/fase kematian. Dan pada fermentasi asam asetat, terjadi reaksi aerob, yaitu perubahan alkohol menjadi asam asetat dan air oleh bakteri Acetobacter aceti (Salle,1974).

Tabel 5. Nilai rata-rata kadar alkohol (\%) cuka kakao.

\begin{tabular}{ccccccc}
\hline \multirow{2}{*}{$\begin{array}{c}\text { Lama fermentasi } \\
\text { (Hari) }\end{array}$} & \multicolumn{7}{c}{ Konsentrasi Penambahan Ragi Tape (\%) } & \multirow{2}{*}{ Rata-rata } \\
\cline { 2 - 6 } & 0 & 0,05 & 0,10 & 0,15 & 0,20 & \\
\hline 5 & 4,50 & 4,50 & 4,48 & 4,48 & 4,48 & $4,49 \pm 0,01^{\mathrm{a}}$ \\
10 & 2,42 & 2,42 & 2,41 & 2,41 & 2,41 & $2,41 \pm 0,00^{\mathrm{ab}}$ \\
15 & 0,00 & 0,00 & 0,00 & 0,00 & 0,00 & $0,00 \pm 0,00^{\mathrm{b}}$ \\
20 & 0,00 & 0,00 & 0,00 & 0,00 & 0,00 & $0,00 \pm 0,00^{\mathrm{b}}$ \\
25 & 0,00 & 0,00 & 0,00 & 0,00 & 0,00 & $0,00 \pm 0,00^{\mathrm{b}}$ \\
30 & 0,00 & 0,00 & 0,00 & 0,00 & 0,00 & $0,00 \pm 0,00^{\mathrm{b}}$ \\
\hline Rata-rata & $1,15 \pm 1,90^{\mathrm{a}}$ & $1,15 \pm 1,90^{\mathrm{a}}$ & $1,15 \pm 1,90^{\mathrm{a}}$ & $1,15 \pm 1,90^{\mathrm{a}}$ & $1,15 \pm 1,90^{\mathrm{a}}$ & \\
\hline
\end{tabular}

Keterangan: Huruf yang berbeda di belakang nilai rata-rata pada baris atau kolom yang sama menunjukkan adanya perbedaan yang nyata $(\mathrm{P}<0,05)$. Data merupakan rata-rata dari dua kelompok percobaan.

\section{Uji efektivitas}

Hasil uji indeks efektivitas untuk menentukan perlakuan terbaik pada cuka kakao fermentasi yang ditambahkan ragi tape. Hasil uji indeks efektivitas dapat dilihat pada Tabel 6.

Tabel 6. Hasil uji indeks efektivitas

\begin{tabular}{|c|c|c|c|c|c|c|}
\hline Variabel & & $\begin{array}{c}\text { Kadar asam } \\
\text { asetat }\end{array}$ & $\mathrm{pH}$ & TPT & $\begin{array}{l}\text { Total } \\
\text { gula }\end{array}$ & Jumlah \\
\hline & $(\mathrm{BV})$ & 5,00 & 4,00 & 3,33 & 2,67 & 15,00 \\
\hline & $(\mathrm{BN})$ & 0,33 & 0,27 & 0,22 & 0,18 & 1,00 \\
\hline H5R0 & $\mathrm{Ne}$ & 0,00 & 0,00 & 0,00 & 0,15 & \\
\hline (Fermentasi hari ke-5 \& penambahan ragi $0 \%$ ) & $\mathrm{Nh}$ & 0,00 & 0,00 & 0,00 & 0,03 & 0,03 \\
\hline H5R1 & $\mathrm{Ne}$ & 0,01 & 0,07 & 0,00 & 0,31 & \\
\hline (Fermentasi hari ke-5 \& penambahan ragi $0,05 \%$ ) & $\mathrm{Nh}$ & 0,00 & 0,02 & 0,00 & 0,05 & 0,08 \\
\hline H5R2 & $\mathrm{Ne}$ & 0,28 & 0,19 & 0,12 & 0,23 & \\
\hline (Fermentasi hari ke-5 \& penambahan ragi $0,15 \%)$ & $\mathrm{Nh}$ & 0,09 & 0,05 & 0,03 & 0,04 & 0,21 \\
\hline H5R3 & $\mathrm{Ne}$ & 0,44 & 0,33 & 0,21 & 0,23 & \\
\hline (Fermentasi hari ke-5 \& penambahan ragi $0,15 \%)$ & $\mathrm{Nh}$ & 0,15 & 0,09 & 0,05 & 0,04 & 0,32 \\
\hline H5R4 & $\mathrm{Ne}$ & 0,44 & 0,32 & 0,19 & 0,00 & \\
\hline (Fermentasi hari ke-5 \& penambahan ragi $0,20 \%)$ & $\mathrm{Nh}$ & 0,15 & 0,08 & 0,04 & 0,00 & 0,27 \\
\hline H10R0 & $\mathrm{Ne}$ & 0,03 & 0,14 & 0,17 & 0,31 & \\
\hline (Fermentasi hari ke-10 \& penambahan ragi 0\%) & $\mathrm{Nh}$ & 0,01 & 0,04 & 0,04 & 0,05 & 0.14 \\
\hline
\end{tabular}




\begin{tabular}{|c|c|c|c|c|c|c|}
\hline H10R1 & $\mathrm{Ne}$ & 0,04 & 0,19 & 0,17 & 0,38 & \\
\hline (Fermentasi hari ke- 10 \& penambahan ragi $0,05 \%$ ) & $\mathrm{Nh}$ & 0,01 & 0,05 & 0,04 & 0,07 & 0,17 \\
\hline H10R2 & $\mathrm{Ne}$ & 0,25 & 0,26 & 0,27 & 0,46 & \\
\hline (Fermentasi hari ke-10 \& penambahan ragi $0,10 \%$ ) & $\mathrm{Nh}$ & 0,08 & 0,07 & 0,06 & 0,08 & 0,29 \\
\hline H10R3 & $\mathrm{Ne}$ & 0,53 & 0,40 & 0,39 & 0,46 & \\
\hline (Fermentasi hari ke-10 \& penambahan ragi $0,15 \%)$ & $\mathrm{Nh}$ & 0,18 & 0,11 & 0,09 & 0,08 & 0,45 \\
\hline H10R4 & $\mathrm{Ne}$ & 0,51 & 0,40 & 0,36 & 0,54 & \\
\hline (Fermentasi hari ke-10 \& penambahan ragi $0,20 \%)$ & $\mathrm{Nh}$ & 0,17 & 0,11 & 0,08 & 0,10 & 0,46 \\
\hline H15R0 & $\mathrm{Ne}$ & 0,09 & 0,26 & 0,42 & 0,46 & \\
\hline (Fermentasi hari ke-15 \& penambahan ragi $0 \%)$ & $\mathrm{Nh}$ & 0,03 & 0,07 & 0,09 & 0,08 & 0,27 \\
\hline H15R1 & $\mathrm{Ne}$ & 0,11 & 0,33 & 0,41 & 0,54 & \\
\hline (Fermentasi hari ke-15 \& penambahan ragi $0,05 \%$ ) & $\mathrm{Nh}$ & 0,04 & 0,09 & 0,09 & 0,10 & 0,31 \\
\hline $\mathrm{H} 15 \mathrm{R} 2$ & $\mathrm{Ne}$ & 0,30 & 0,39 & 0,48 & 0,54 & \\
\hline (Fermentasi hari ke-15 \& penambahan ragi $0,10 \%$ ) & $\mathrm{Nh}$ & 0,10 & 0,10 & 0,11 & 0,10 & 0,41 \\
\hline H15R3 & $\mathrm{Ne}$ & 0,54 & 0,53 & 0,59 & 0,62 & \\
\hline $\begin{array}{l}\text { (Fermentasi hari ke- } 15 \& \\
\text { penambahan ragi } 0,15 \%)\end{array}$ & $\mathrm{Nh}$ & 0,18 & 0,14 & 0,13 & 0,11 & 0,56 \\
\hline H15R4 & $\mathrm{Ne}$ & 0,52 & 0,51 & 0,58 & 0,62 & \\
\hline (Fermentasi hari ke-15 \& penambahan ragi $0,20 \%$ ) & $\mathrm{Nh}$ & 0,17 & 0,14 & 0,13 & 0,11 & 0,55 \\
\hline H20R0 & $\mathrm{Ne}$ & 0,14 & 0,37 & 0,42 & 0,62 & \\
\hline (Fermentasi hari ke-20 \& penambahan ragi $0 \%$ ) & $\mathrm{Nh}$ & 0,05 & 0,10 & 0,09 & 0,11 & 0,35 \\
\hline H20R1 & $\mathrm{Ne}$ & 0,18 & 0,42 & 0,48 & 0,69 & \\
\hline (Fermentasi hari ke-20 \& penambahan ragi $0,05 \%$ ) & $\mathrm{Nh}$ & 0,06 & 0,11 & 0,11 & 0,12 & 0,40 \\
\hline $\mathrm{H} 20 \mathrm{R} 2$ & $\mathrm{Ne}$ & 0,39 & 0,49 & 0,47 & 0,69 & \\
\hline (Fermentasi hari ke-20 \& penambahan ragi $0,10 \%)$ & $\mathrm{Nh}$ & 0,13 & 0,13 & 0,10 & 0,12 & 0,49 \\
\hline H20R3 & $\mathrm{Ne}$ & 0,65 & 0,61 & 0,62 & 0,85 & \\
\hline (Fermentasi hari ke-20 \& penambahan ragi $0,15 \%)$ & $\mathrm{Nh}$ & 0,22 & 0,16 & 0,14 & 0,15 & 0,67 \\
\hline H20R4 & $\mathrm{Ne}$ & 0,64 & 0,61 & 0,60 & 0,85 & \\
\hline (Fermentasi hari ke-20 \& penambahan ragi $0,20 \%$ ) & $\mathrm{Nh}$ & 0,21 & 0,16 & 0,13 & 0,15 & 0,66 \\
\hline $\mathrm{H} 25 \mathrm{R} 0$ & $\mathrm{Ne}$ & 0,24 & 0,53 & 0,53 & 0,69 & \\
\hline (Fermentasi hari ke-25 \& penambahan ragi $0 \%)$ & $\mathrm{Nh}$ & 0,08 & 0,14 & 0,12 & 0,12 & 0,46 \\
\hline $\mathrm{H} 25 \mathrm{R} 1$ & $\mathrm{Ne}$ & 0,30 & 0,61 & 0,57 & 0,77 & \\
\hline (Fermentasi hari ke- 25 \& penambahan ragi $0,05 \%$ ) & $\mathrm{Nh}$ & 0,10 & 0,16 & 0,13 & 0,14 & 0,53 \\
\hline $\mathrm{H} 25 \mathrm{R} 2$ & $\mathrm{Ne}$ & 0,50 & 0,74 & 0,61 & 0,77 & \\
\hline (Fermentasi hari ke-25 \& penambahan ragi $0,10 \%$ ) & $\mathrm{Nh}$ & 0,17 & 0,20 & 0,14 & 0,14 & 0,64 \\
\hline H25R3 & $\mathrm{Ne}$ & 0,70 & 0,84 & 0,91 & 0,85 & \\
\hline (Fermentasi hari ke-25 \& penambahan ragi $0,15 \%$ ) & $\mathrm{Nh}$ & 0,23 & 0,22 & 0,20 & 0,15 & 0,81 \\
\hline $\mathrm{H} 25 \mathrm{R} 4$ & $\mathrm{Ne}$ & 0,70 & 0,82 & 0,97 & 0,85 & \\
\hline (Fermentasi hari ke-25 \& penambahan ragi $0,20 \%$ ) & $\mathrm{Nh}$ & 0,23 & 0,22 & 0,21 & 0,15 & 0,82 \\
\hline
\end{tabular}




\begin{tabular}{|l|c|c|c|c|c|c|}
\hline H30R0 & $\mathrm{Ne}$ & 0,31 & 0,75 & 0,46 & 0,69 & \\
\hline (Fermentasi hari ke-30 \& penambahan ragi 0\%) & $\mathrm{Nh}$ & 0,10 & 0,20 & 0,10 & 0,12 & 0,53 \\
\hline H30R1 & $\mathrm{Ne}$ & 0,43 & 0,75 & 0,88 & 0,77 & \\
\hline (Fermentasi hari ke-30 \& penambahan ragi 0,05\%) & $\mathrm{Nh}$ & 0,14 & 0,20 & 0,20 & 0,14 & 0,68 \\
\hline H30R2 & $\mathrm{Ne}$ & 0,57 & 0,91 & 0,85 & 0,77 & \\
\hline (Fermentasi hari ke-30 \& penambahan ragi 0,10\%) & $\mathrm{Nh}$ & 0,19 & 0,24 & 0,19 & 0,14 & 0,76 \\
\hline H30R3 & $\mathrm{Ne}$ & 1,00 & 1,00 & 1,00 & 0,92 & \\
\hline (Fermentasi hari ke-30 \& penambahan ragi 0,15\%) & $\mathrm{Nh}$ & 0,33 & 0,27 & 0,22 & 0,16 & 0,99 \\
\hline H30R4 & $\mathrm{Ne}$ & 0,90 & 1,00 & 0,98 & 1,00 & \\
\hline (Fermentasi hari ke-30 \& penambahan ragi 0,20\%) & $\mathrm{Nh}$ & 0,30 & 0,27 & 0,22 & 0,18 & 0,96 \\
\hline
\end{tabular}

Keterangan:

$\mathrm{Ne}=$ nilai efektivitas

$\mathrm{BV}=$ bobot variabel

$\mathrm{Nh}=$ nilai hasil $(\mathrm{Ne} \times \mathrm{BN})$

$\mathrm{BN}=$ bobot normal

Perlakuan terbaik ditunjukkan dengan nilai tertinggi dari penjumlahan nilai $(\mathrm{Nh})$ pada tiap variabel. Tabel 6 menunjukkan bahwa cuka fermentasi yang ditambahkan ragi tape dengan perlakuan terbaik yaitu pada perlakuan 30 hari fermentasi dan penambahan ragi tape $0,15 \% \quad(b / v)$ mempunyai nilai terbaik yaitu 0,99 . Hal tersebut menunujukkan bahwa perlakuan 30 hari fermentasi dan penambahan ragi tape $0,15 \%(\mathrm{~b} / \mathrm{v})$ merupakan perlakuan terbaik yang menghasilkan cuka kakao.

\section{KESIMPULAN DAN SARAN}

\section{Kesimpulan}

Berdasarkan penelitian yang telah dilakukan maka dapat disimpulkan beberapa hal sebagai berikut:

1. Perlakuan penambahan ragi tape berpengaruh sangat nyata terhadap asam asetat, $\mathrm{pH}$, total padatan terlarut, total gula, berpengaruh tidak nyata terhadap kadar alkohol pada cuka fermentasi dari cairan pulpa hasil samping fermentasi biji kakao. Perlakuan lama fermentasi berpengaruh sangat nyata terhadap asam asetat, $\mathrm{pH}$, total padatan terlarut, total gula, alkohol. Interaksi antara kedua perlakuan berpengaruh tidak nyata terhadap asam asetat, $\mathrm{pH}$, total padatan terlarut, kadar alkohol, dan berpengaruh sangat nyata terhadap total gula pada produk cuka kakao fermentasi.

2. Perlakuan terbaik diperoleh dari penambahan konsentrasi ragi tape 0,15 $\%(\mathrm{~b} / \mathrm{v})$ dan waktu fermentasi 30 hari yang menghasilkan cuka kakao dengan kadar asam asetat 2,40\%, pH 3,37, total padatan terlarut $4,25{ }^{\circ}$ brix, total gula $0,03 \%$, dan alkohol $0,00 \%$.

\section{Saran}

Perlu dilakukan penelitian lebih lanjut tentang pemanfaatan cuka kakao secara komersial untuk cuka fermentasi dan perlu dilakukan penelitian untuk memperoleh kadar asam asetat yang lebih maksimal.

\section{DAFTAR PUSTAKA}

Adam, M.R. 1985. Microbiology of Fermented Food Vol 1. Elsivier Applied Science Publisher, Ltd., New York.

Adrista, G.G., N.M. Wartini dan W. Arnata. 2016. Pengaruh penambahan etanol dan lama fermentasi lanjutan cairan pulpa hasil samping fermentasi biji 
kakao terhadap karakteristik cuka kakao. Jurnal Rekayasa Dan Manajemen Agroindustri. 4(4):1-11.

Apriyantono, A., D. Fardiaz, N.L.P. Pitasari, S. Yasni dan S. Budiyanto. 1988. Penuntun Praktek Analisis Pangan. Pusat Antar Universitas Pangan dan Gizi. Institut Pertanian Bogor, Bogor.

Aridona, P.M., N.M. Wartini dan I W. Arnata. 2015. Pengaruh lama fermentasi alami cairan pulpa hasil samping fermentasi biji kakao terhadap rendemen dan karakteristik cuka fermentasi. Jurnal Rekayasa Dan Manajemen Agroindustri. 3(3):85-92.

Alamsyah, T.S. 1991. Peranan fermentasi dalam pengolahan biji kakao kering. Jurnal Berita Perkebunan, 1 (2): $97-$ 106.

Daulay, D dan A. Rahman 1992. Teknologi Fermentasi Sayuran dan Buah-Buahan. PAU Pangan dan Gizi IPB, Bogor.

De Garmo, E.P., W.G. Sullivan and J.R. Canada. 1984. Engineering Economy $\left(\begin{array}{ll}7^{\text {th }} & \text { ed). Macmillan Publishing }\end{array}\right.$ Company, New York.

Direktorat Jenderal Perkebunan. 2012. Pedoman Teknis Penanganan Pascapanen Kakao. Direktur Jenderal Perkebunan, Jakarta.

Direktorat Jenderal Perkebunan. 2015. Statistik Perkebunan Indonesia 20142016: Komoditas Kakao. Direktorat Jenderal Perkebunan, Jakarta.

Ganda-Putra, G.P., Harijono, S. Kumalaningsih dan Aulani'am. 2008. Optimasi kondisi depolimerisasi pulp biji kakao oleh enzim poligalakturonase endojinus. Jurnal Teknik Industri. 9 (1):24-34.

Ganda-Putra G.P., L.P. Wrasiati dan N.M. Wartini. 2010. Proses fermentasi kakao berbasis kondisi optimum depolimerisasi pektin pulpa oleh enzim-enzim pektolitik endogen. Jurnal Pelita Perkebunan. 26(2):115-125.

Ganda-Putra G.P. dan N.M. Wartini. 2016. Pengaruh penambahan ragi tape selama fermentasi terhadap karakteristik cairan pulpa hasil samping fermentasi kakao untuk produksi cuka makan. Agrotechno. 1(1):46-50.

Hardoyo., A.E. Tjahjono, D. Primarini, Hartono dan Musa. 2007. Kondisi optimum fermentasi asam asetat menggunakan Acetobacter aceti B166. Jurnal Sains MIPA. 13(1):17-20.

Harijono, J. Kusnadi dan S.A. Mustikasari. 2001. Pengaruh kadar karaginan dan total padatan terlarut sari buah apel muda terhadap aspek kualitas permen jelly. Jurnal Teknologi Pertanian. 2(2):110-116.

Haryadi dan M. Supriyanto. 1991. Pengolahan Kakao Menjadi Bahan Pangan. Pusat Antar Universitas. Universitas Gadjah Mada, Yogyakarta.

Januaresti, A. 2016. Pengaruh konsentrasi inokulum Acetobacter aceti dan lama fermentasi terhadap karakteristik vinegar murbei (Morus alba). Skripsi S1. Fakultas Teknik Universitas Pasundan, Bandung.

Lehninger. 1982. Dasar-Dasar Biokimia. Erlangga, Jakarta.

Luwihana, S., K.R. Kuswanto, E.S. Rahayu dan S. Sudarmadji. 2010. Fermentasi asam asetat dengan sel amobil Acetobacter pasteurianus INT-7 dengan variasi $\mathrm{pH}$ awal dan kadar etanol. Agritech. 30(2): 123-132.

Nurismanto, R., T. Mulyani dan D.I.N. Tias. 2014. Pembuatan asam cuka pisang kepok (Musaparadisiaca L.) dengan kajian lama fermentasi dan konsentrasi 
inokulum (Acetobacteracetii). Jurnal Rekapangan. 8(2):149-155.

Putri, A.G.S.I.M., G.P. Ganda-Putra dan W. Arnata. 2016. Pengaruh penambahan inokulum Saccharomycess cerevisiae dan lama fermentasi terhadap karakteristik cuka fermentasi dari cairan pulpa hasil samping fermentasi biji kakao (Theobroma Cacao L). Jurnal Rekayasa dan Manajemen Agroindustri. 4(3):71-84.

Salle, A.J. 1974.Fundamental Principles of Bacteriology. Tata Mc Graw Hill, New Delhi.

Sintasari, R.A., J. Kusnadi dan D.W. Ningtyas. 2014. Pengaruh penambahan konsentrasi susu skim dan sukrosa terhadap karakterisik minuman probiotik sari beras merah. Jurnal Pangan dan Agroindustri. 2(3): 65-75.

SNI 01-3711-1995. Standar Nasional Indonesia (SNI) Cuka Makan. Badan Standardisasi Nasional (BSN), Jakarta.

SNI 01-4371-1966. Standar Nasional Indonesia (SNI) Cuka Fermentasi. Badan Standardisasi Nasional (BSN), Jakarta.

Sudarmadji, S., B. Haryono dan Suhardi. 1989. Analisis Bahan Pangan dan Hasil Pertanian. Liberty, Yogyakarta.

Susanto, H. 1992. Kakao: Budidaya, Pengolahan Hasil dan Aspek Ekonomisnya. Kanisius, Yogyakarta.
Susilowati, A., dan P. A. Wati. 2001. Kajian awal pembuatan "Vinegar" dari air kelapa dan limbah cair embuatan "Nata de Coco" dengan Metode "Quick Process". Biosmart. 3(2):13-17.

Towaha, J. 2013. Diversifikasi produk berbasis pulpa kakao. Jurnal Sirinov. 1(2):57-74.

Waluyo, S. 1984. Beberapa Aspek Tentang Pengolahan Vinegar. Dewaruci Press, Jakarta.

Wang, D. I. C., C. L. Conney, A. L. Demain, P. Punhail, A. E. Humprey and M. D. Lily. 1979. Fermentation and Enzyme Tecnology. Jhon Wiley and Sons Inc., New York.

Wardojo, S. 1991. Beberapa persyaratan dasar untuk meningkatkan mutu biji kakao indonesia. prosiding konperensi nasional kakao III, Medan. p: 75-85.

Wartini, N.M., L.P. Wrasiati dan A.A.M.D. Anggreni. 2014. Petunjuk Praktikum Pengetahuan Bahan Pangan. Jurusan Teknologi Industri Pertanian. Fakultas Teknologi Pertanian. Universitas Udayana., Bukit Jimbaran. 